\title{
Ambush Marketing and Rule 40 for Tokyo 2020: A Shifting Landscape for Olympic Athletes and Their Sponsors
}

\author{
Steve McKelvey, John Grady, and Anita M. Moorman*
}

\begin{abstract}
This study explores the historical development of the regulatory landscape related to Olympic and Paralympic athlete marketing activities, together with current restrictions imposed on athlete marketing, and discusses potential legal challenges to these restrictions. Specifically, this study analyzed various countries' Rule 40 Tokyo 2020 guidance through a trans-national lens by comparing and contrasting the different approaches found in various national Olympic committees' legal frameworks to combat ambush marketing. The potential legal challenges to the United States Olympic Commititee's enforcement of new Rule 40 guidance are highlighted, with particular focus on discussing the restrictions and enforcement rights contained within the personal sponsor commitment agreement within the United States for the postponed Tokyo 2020 Games. Critical analysis of the potential impact of enforcing this agreement within the broader Olympic intellectual property and brand protection frameworks for Olympic stakeholders in the US is provided.
\end{abstract}

Keywords: Olympics, trademark enforcement, intellectual property, ambush marketing, Rule 40

\footnotetext{
Steve McKelvey, JD, is a professor and chair in the Mark H. McCormack Department of Sport Management in the Isenberg School of Management at the University of Massachusetts Amherst. His research focuses primarily on the legal and practical application of intellectual property law issues to the sports marketing and sponsorship industry. He has researched extensively on ambush marketing. Email: mckelvey@isenberg.umass.edu

John Grady, JD, PhD, is a professor of sport and entertainment management at the University of South Carolina. His current research interests are focused primarily on legal issues in sport sponsorship, including ambush marketing strategies, Rule 40 enforcement, and intellectual property protection. Email: igrady@sc.edu
}

Anita M. Moorman, JD, is a professor of sport administration at the University of Louisville. She teaches sport law and legal aspects of sport. Her research interests include the unique impact numerous Supreme Court decisions have had in the sport industry with a focus on participant rights issues in sport. She also examines contractual transactions in sport and the interplay between sport law and marketing. Email: anita.moorman@louisville.edu

*All authors contributed equally to this manuscript. 


\section{Introduction}

As the Olympic Games continues to be "the premier event in terms of sponsorship attractiveness," numerous legal issues emerge surrounding the intersection of interests related to official sponsor protection, ambush marketing, and athlete endorsements by non-Olympic sponsors (Chavanat \& Desbordes, 2014, p. 155). Olympic properties have attacked this ongoing problem on multiple legal fronts to protect official sponsors at each Olympic Games, including aggressive brand policing, trademark infringement actions targeting unauthorized use of Olympic marks featuring athletes, and more recent attempts to regulate social media as brands transition primarily to digital and social media to activate sponsorships. In addition, host countries enacted special laws providing added protections for Olympic sponsors regarding the use of Olympic marks and phrases leading up to and during the Games (Clark, 2016; Grady, 2021; Louw, 2012; Nakamura, 2018; Scassa, 2014; Smart \& Biggar, 2018; Wüthrich, 2016). For many years, Olympic sport organizations have attempted to claim ownership of the publicity associated with the Games and of the potential for advertisers to grab the public's attention associated with the Olympics (Louw, 2012). This is generally referred to as the thematic space associated with the Olympic Games and has historically been exclusively reserved for the Games' official sponsors. However, as the Olympic marketing and sponsorship landscape has shifted, the exponential growth of "social media has helped create the perfect storm to fuel ambush marketing at an amplified level" and further enable non-official sponsors to activate marketing campaigns in the Olympic thematic space (Grady, 2016, p. 2). This has necessitated developing new legal protections in the form of more aggressive and innovative enforcement of regulations in the Olympic Charter related to use of athletes' name, image, and likeness and athlete marketing activities (International Olympic Committee, n.d.a). The International Olympic Committee (IOC) regulation at issue in this study is Rule 40, which restricts certain advertising and marketing activities by Olympic and Paralympic athletes and their personal sponsors prior to and during the Olympic Games. Even though the title refers to "commercial opportunities," Rule 40 restricts how competing Olympic and Paralympic athletes can be used in advertising when their personal sponsor is not also an official sponsor of the Games (IOC, 2019). Specifically, for Team USA athletes, the current iteration of Rule 40 allows athletes' personal sponsors to use the name, image, and likeness of their athletes for marketing purposes, but advertising must not draw a specific Olympic connection when it involves non-Olympic sponsor brands, and also places limits on the number of social media messages by athletes and their personal sponsors (McKelvey, Grady, \& Moorman, 2020). 
The IOC's restrictions have not gone unchallenged. Athletes in particular have argued that their rights to commercialize their participation in the Games, when their commercial value to engage with sponsors is at its peak, have been unfairly hindered by Olympic marketing restraints. In response to athletes questioning the application of IOC marketing restraints and negative media publicity surrounding those restraints, the IOC has continued to revise the regulations in an effort to give athletes more freedom in terms of advertising with their personal sponsors while still preserving the exclusivity official sponsors have been promised in sponsorship rights agreements. Legal scholars and practitioners have also questioned the legitimacy of special legislation to protect commercial interests to the Olympics (Louw, 2012; Scassa, 2014). In practice this has resulted in somewhat of a "Wild West" situation, especially on social media, where, for each Olympic Games, the IOC adopts revised policy guidance for enforcing athlete marketing restraints, which triggers National Olympic Ccommittees (NOCs) to issue new guidance for each country's athletes and personal sponsors. This results in slight variations in the Rule 40 guidance for each country and causes uncertainty and confusion for athletes, agents, and their personal sponsors about what marketing activities are permitted for each respective Games (Blevins, 2014).

The purpose of this paper is to explore the historical development of the regulatory landscape related to Olympic and Paralympic athlete marketing activities together with the current restrictions imposed on athletes and discuss potential legal challenges to these restrictions. Part I provides a brief history of the purpose and evolution of Rule 40 and the legal challenge asserted by the German Federal Cartel Office (FCO), which triggered the IOC's overarching and comprehensive changes in advance of the postponed 2020 Tokyo Summer Games. Part II compares and contrasts the regulatory framework established in response to the IOC's Tokyo 2020 Rule 40 revisions by various NOCs in their respective Rule 40 policies. Lastly, Part III explores in detail the approach adopted by the United States Olympic and Paralympic Committee (USOPC) to include a contract-based Personal Sponsor Commitment (PSC) process, raising a number of legal questions and concerns regarding the scope and potential enforceability of this agreement. This final section examines a number of contract law-related issues (including the vagueness of numerous provisions, the "click-wrap" method of agreement, and the restrictive covenant provisions), as well as the more practical concerns and their anticipated impact on athletes and their personal sponsors. This analysis will allow legal scholars and practitioners to better understand how Rule 40 may be applied as athletes, agents, and their personal sponsors prepare for the Tokyo Games and the legal challenges that may result from this new contractual paradigm for USOC rules enforcement. 


\section{History and Background of Rule $\mathbf{4 0}$ of the Olympic Charter}

Rule 40 of the Olympic Charter defines participation rights in the Olympic Games and requires participants (competitors, officials, and team personnel) to respect and comply with the Olympic Charter, including any conditions of participation established by the IOC (IOC, 2019). Bye-law 3 to Rule 40 is titled "commercial opportunities for participants during the Tokyo 2020 Olympic Games" (IOC, 2019). Throughout this paper, the provisions on athlete marketing activities are referred to under the umbrella term of "Rule 40" or "Rule 40.3" restrictions. While acknowledging the need to provide Olympic athletes and their personal sponsors a broader opportunity to commercially capitalize on their name and likeness during the Tokyo Games, the IOC's major directive was to allow each national governing body (NGB) to establish its own guidelines for the application of Rule 40.3.

As a main point of contention for the three most recent Olympic Games preceding Tokyo 2020, Rule 40 of the Olympic Charter restricted how competing Olympic athletes could be used in advertising when their personal sponsor was not also an official sponsor of the Games. Specifically, Bye-law 3 of Rule 40 stated that, "Except as permitted by the IOC Executive Board, no competitor, coach, trainer or official who participates in the Olympic Games may allow his person, name, picture or sports performances to be used for advertising purposes during the Olympic Games" (IOC, n.d.b). This older version of Rule 40 also created a "blackout" or "frozen period" where athletes' personal sponsor brands that were not official Olympic sponsors were prohibited from using the athletes' name, image, or sport performance in advertising for approximately three weeks surrounding the Games (Tsvetanova, 2020).

The "blackout period" generated the most controversy among athletes and their personal sponsors. Brands that weren't official Olympic sponsors (referred to as non-affiliated brands) were not permitted to use protected words (or "banned words"), such as "Olympics," "Rio 2016," and even "Summer" (Given, 2016; Li, 2016). Further, other protected Olympic intellectual property, notably the Olympic rings and event logos, was not allowed to be used in advertising during the blackout period (IOC, n.d.b).

The purpose and policy reasons for Rule 40, as stated by the IOC, are: "[t]o preserve the unique nature of the Olympic games by preventing over-commercialization," "to allow the focus to remain on athletes," and to protect the Olympics' source of funding, essentially the sponsorship revenues and Olympic sponsors (IOC, 2019, p. 2). While generating significant controversy and backlash among athletes and advocates, Rule 40 has been generally effective, primarily in 
protecting official sponsors' exclusivity as the practice of ambush marketing has shifted toward social media (Rovell, 2016).

\section{A. The Olympic Rule 40 Enforcement Process}

While the IOC retains authority in setting the parameters for how Rule 40 will be applied for each Games, each national organizing committee (NOC) has the ultimate responsibility to enforce the rule within their territory (i.e., advertising within that country, and which involves their athletes) and ensure compliance with the rule by that country's competing athletes and other accredited persons. To date, "no U.S. court has definitely ruled on the legitimacy of the parameters and reach of Rule 40 and its application" (Epstein, 2017, p. 373). Inevitably, this has resulted in a patchwork of practical guidance from each NOC, each with slight variations due to the legal framework within that country as well as policy considerations taken by each NOC to address athletes' and other stakeholders' concerns particular to that country. The guidance developed by each NOC is intended to help clarify some of these marketing scenarios and permissible activities for athletes and their personal sponsors (Grady, 2017).

London 2012. Enforcement of Rule 40 was most prominent during the London 2012 Summer Games, with "brand police" taking a heavy-handed approach to protect official sponsor brands and clamp down on arguably unauthorized marketing activities involving athletes. Local businesses also got swept up in the aggressive brand protection efforts (Grady \& McKelvey, 2012). Butcher shops, lingerie shops, and local pubs became the target of overzealous local organizing committees for the Olympic Games (OCOGs) — brand protection officers seeking to protect Olympic intellectual property, notably unauthorized use of the Olympic rings (Grady \& McKelvey, 2012). While "Rule 40, in practical effect, helps achieve the IOC's brand protection measures by (in theory) eliminating brand exposure by non-sponsors during the Games," this overzealous approach did not go unchallenged (Grady \& McKelvey, 2015, p. 1).

Implementation of Rule 40 has also raised ongoing legal concerns about advertising restrictions placed on competing athletes' abilities to acknowledge their personal sponsors when those sponsors are not also official Olympic sponsors (Grady, 2016). During London 2012, dubbed the "Social Olympics" or "Twitter Olympics" (Epstein, 2017) Rule 40's legal "teeth" were put to the test, largely on social media. An advertising campaign involving Michael Phelps and Louis Vuitton raised the ire of Olympic organizers when unauthorized images from the campaign were leaked during the blackout period, suggesting the prospect that elite athletes, such as Phelps, might be disqualified for violating Rule 40, an unlikely outcome (Grady \& McKelvey, 2012). Virgin Media pulled ads involving track phenom Usain Bolt to avoid potentially violating Rule 40 (Grady 
\& McKelvey, 2015). Similarly, Red Bull removed athlete pages from its website (Blevins, 2014).

The tension created by Rule 40 and the way it was zealously enforced for London 2012 came to a head when competing athletes, led by U.S. track Olympians Nick Symmonds and Sanya Richards-Ross, began using the hashtag \#wedemandchange2012 to bring attention to the alleged economic unfairness of the rule for athletes (Reynolds, 2012). Per an Olympic financial report, most athletes who do not acquire global or high-profile domestic sponsors will likely never have enough funding to compete with athletes at the top of the respective sport. "... many athletes struggle to pay for training and costs associated with the games due to the full-time training necessary to compete and the inability of the non-profit Olympic organizations to pay athletes with salaries” (Bradish, Koehler, 2019). The rationale behind the unfairness argument underpinning Rule 40 was (and still remains) that athletes' personal sponsors heavily invested in them in order for the athlete to reach the pinnacle of competition, yet are restricted under Rule 40 from being able to advertise about their sponsorship of the athlete during the peak Games period (Belson, 2012).

Rio 2016. After London 2012, with tensions about Rule 40 not subsiding and ambush marketing shifting largely to social media, it became clear to Olympic officials that they would need to re-examine how the rule would be applied in order to give athletes more flexibility $(\mathrm{Li}, 2016)$. This came to a boiling point prior to Rio 2016. Leading up to the Rio 2016 Summer Games, "one of the issues of greatest legal uncertainty was how Olympic officials would manage application and enforcement of Rule 40" (Grady, 2016, p. 1). IOC officials got ahead of the issue, both legally and from a public relations standpoint, by issuing Rule 40 guidance 18 months in advance of the Games. For Rio 2016, the IOC "relaxed" application of the rule significantly to "allow the continuation of in-market generic advertising featuring participants, so long as no direct or indirect association with the Olympics was created," including no use of Olympic intellectual property (IOC, n.d.b).

The IOC directed each NOC to develop a waiver process to pre-approve advertising campaigns by non-official sponsor brands that featured competing athletes (IOC, n.d.b). This new guidance promised to give athletes additional flexibility with regard to advertising restrictions and diverged significantly from the previously strict approaches to Rule 40 that favored official sponsors (Fischer, 2016; Li, 2016). As athletes have become more active in their own brand-building through the use of social media, Grady (2016) predicted relaxing Rule 40 would offer athletes increased commercial opportunities to promote their individual sponsorships as part of sharing their Olympic story. At the time, many Olympic stakeholders, notably official sponsors, were skeptical of the relaxed rule and 
"questioned how such a drastic change would alter the legal and business complexities of the Olympic sponsorship model" (Grady, 2016, p. 1). Global sponsors, in particular, took issue with the relaxed approach, which now allowed more non-affiliated brands into the Olympic marketing space, an area previously reserved exclusively for them.

The "results" from Rio 2016 with regard to Rule 40 application and enforcement were largely as predicted. "The most prominent companies expected to take advantage of the relaxed rules include[d] Under Armour, which ha[d] a major Michael Phelps-anchored campaign ["Rule Yourself"], and Gatorade, which [ran] ads and [sold] special bottles featuring Serena Williams and Usain Bolt, among others" (Fischer, 2016, para.1). The newly relaxed Rule 40 worked especially well for high-profile famous faces like Phelps, but was not as effective in generating new sponsorship opportunities and increased visibility for lesser-known athletes. The rule changes also did not open the field to a wider array of smaller brands that support lesser-known athletes. Brooks Running ran a stealth marketing campaign using Rule40.com tweets to "to spotlight how Rule 40 unfairly penalizes athletes who are not famous" (Li, 2016, p. 1). Likewise, women's athletic leisure brand

Oiselle's CEO was particularly vocal, alleging that even the relaxed Rule 40 for Rio 2016 did not give Olympic athletes enough flexibility to maintain a noticeable marketing presence by their personal sponsors during the Games period (Rovell, 2016; Shontz, 2016). "This precluded almost all but the most powerful global brands from taking full advantage of the ability to featuring Olympic athletes in marketing during the Games and ultimately blunted wider potential impacts of the relaxed rule" (Grady, 2016, p. 2). Furthermore, continued harsh enforcement tactics, including the USOC for the first time asserting trademark protection in its IP when used as hashtags, such as \#Rio2016 (McKelvey \& Grady, 2017), kept smaller brands largely on the sidelines during the Rio Games and unable to take full advantage of a "relaxed" Rule 40 on social media.

\section{B. German Federal Cartel Office Investigates Rule 40}

This lack of uniformity in guidance and enforcement created an opportunity to examine how a 2019 administrative law decision in Germany altered the legal landscape with regard to Rule 40.3 application. Enforcement of Rule 40 has not typically been challenged by legal means. It has been handled through a delicately negotiated process between athletes, Olympic officials, and their NOCs, which are charged with enforcing compliance with all Olympic rules. As discussed, Rule 40 was relaxed by the IOC for the Rio 2016 Summer Games, which provided additional commercial flexibility for athletes and their personal sponsors. Yet, German athletes and their respective personal sponsors still considered the 2016 Rule 40 guidelines to be overly restrictive and unclear. The 
German Federal Cartel Office (FCO) began an investigation in 2017 based on a complaint submitted by the German Association of the Sporting Good Industry (Bundesverband der Sportartikel-Industrie). Individual German athletes as well as the Association of German Athletes (Athleten Deutschland e.V.) also joined in the proceedings.

Competition laws play an important role in European competition policy. Unlike the U.S. antitrust laws, which primarily focus on market efficiency, European competition laws seek to achieve market integration but also emphasize concepts such as consumer welfare and fairness (Van den Bergh \& Camesasca, 2001). Most European competition laws exist as a means for the state to intervene in market processes in order to achieve public goals. Germany developed competition laws earlier than other European systems and German competition laws are considered the best developed and most effectively enforced system in Europe (Quack \& Djelic, 2005). As the FCO is the central institution in the administrative enforcement system in Germany, the challenge presented a significant legal challenge to the IOC and the German NOC's (Deutscher Olympischer Sportbund) (DOSB) Rule 40 guidelines.

Initially after the FCO commenced its investigation, the DOSB relaxed restrictions on German athletes in 2017 and again in 2018 for the PyeongChang Winter Olympics. The FCO also conducted market tests during the 2018 Winter Olympics, specifically testing the impact of the 2018 Rule 40 guidelines on the marketplace. Following these tests, the IOC and DOSB entered into a Commitment Decision (similar to a consent decree) with the FCO in 2019 in part based upon the FOC's preliminary findings that the IOC and DOSB enjoyed a dominant position in the global market for the organization and marketing of the Olympic Games and that the Rule 40 restrictions were so far reaching they could result in an abuse of market power (Cleary Gottlieb, 2019). The FCO did not determine as a matter of law that Rule 40 violated German competition law, only that it might. In support of its finding, the FCO observed that the market for the organization and marketing of the Olympic Games constitute a relevant product market under Section 19(1) of the German Act against Restraints of Competition (ARC). The FCO further concluded that the organization of the Games and the marketing of the Games were complementary segments of a uniform product market rather than separate markets (FCO, 2019). The FCO generally found that current protections afforded the IOC and DOSB under trademark, copyright, and the German Act on the Protection of the Olympic Emblem and Olympic Names were sufficient safeguards to prevent ambush marketing (Cleary Gottlieb, 2019). The FCO further considered the 2016 Rule 40 guidelines as too restrictive, going so far as disallowing athletes and personal sponsors from using the terms "games," "gold," "silver," and "bronze," or any use of photos from present or past Olympic Games. 
The legal challenge within Germany demonstrates the potential for other European countries to successfully challenge Rule 40 as a violation of competition laws. Butler (2017) suggested athletes in other European countries could file similar challenges, leading to a domino effect where similar decisions are made across Europe. For example, Section 5 of the Irish Competition Act 2002 similarly prohibits the abuse by one or more undertakings of a dominant position, leaving legal experts to question if the Irish Competition and Consumer Protection Commission may also have considered Rule 40 with regard to Irish athletes in advance of the Tokyo 2020 Olympic Games (Fry, 2018). Moreover, given the expansion of private enforcement options under EU competition laws, the FCO decision may empower athletes to continue to challenge rules they see as too restrictive and where the athletes and their potential sponsors could be abused and the marketing of the individual athlete restricted (Butler, 2017).

From a practical perspective, the German complaint showed little hesitation on the part of German regulators to challenge established Olympic rules and practices where regulators spot potential abuses and see less restrictive means available. Thus far in the US, athletes challenging USOC advertising restrictions have not been successful. In 2016, Gold Medal, LLC brought an antitrust suit against USA Track \& Field and the USOC (USATF) challenging the advertising restrictions imposed during the USA Olympic Trials event (Gold Medal v. USATF, 2016). The federal district court held that NGBs and the USOC enjoy an implied immunity from antitrust claims when they act in furtherance of their statutory mandate under the Amateur Sports Act (ASA) (Gold Medal, 2016). On appeal to the Ninth Circuit Court of Appeals, the appellate court observed that implied antitrust immunity can be justified upon a showing of a clear repugnancy between antitrust law and the regulatory system creating the restraint (Gold Medal, 2018). The ASA requires NGBs to organize, finance, and control representation of the US in the Olympic Games and further grants the USOC and NGBs broad authority to fund the Olympic mission through advertising and sponsorships. Therefore, the court of appeals agreed with the district court and held that application of antitrust law to the advertising restrictions would undermine the regulatory system and unduly interfere with the operation of the ASA (Gold Medal, 2018). The Gold Medal case was just the latest federal court decision challenging USOC or NGB restrictions under antitrust law (see, Behagen v. ABA, 1989 and JES Props v. USA Equestrian, 2006 also recognizing implied immunity from antitrust scrutiny).

Even though past antitrust challenges to USOC and NGB restrictions in the US have been unsuccessful, it is likely challenges will continue to be asserted both in the US and in other nations. These continuing legal challenges further support the need for additional flexibility to support Olympic athletes' 
commercial opportunities during the peak of competition and emphasize the importance of understanding revisions and updates to the Rule 40 guidelines. The 2020 Rule 40 guidelines closely parallel with the FCO commitment decision. Therefore, we next examine the 2020 Rule 40 guidelines planned to apply to the 2020 Tokyo Olympic Games, which are now slated for implementation in 2021 (Cohen, 2020).

\section{Rule 40 Guidelines for Tokyo 2020 Olympic Games}

The IOC once again revised Rule 40 in anticipation of the upcoming Tokyo 2020 Olympics. As discussed in the previous section, these revisions were in response to and also informed by the FCO's investigation and preliminary findings (Gottlieb, 2019). In a June 2019 announcement of the "new" Rule 40 for Tokyo 2020, the IOC stated that the amendment permits athletes and other participants to allow their person, name, picture or sports performance to be used for advertising purposes in accordance with the principles determined by the IOC Executive Board (IOC, n.d.a). At first glance it appears to be a significant departure from previous Rule 40 constraints and adopts "permissive" language. Tokyo 2020 Rule 40 , instead of adopting the previous blanket prohibition to advertising (which would have been a clear violation of the Commitment Decisions entered into with the FCO), adopts a two-level enforcement process. Multinational advertising campaigns are required to be operated in compliance within the new IOC 2020 Rule 40 guidelines. For example, Nike's 2016 advertising campaign featuring British long distance runner Mo Farah was part of a multi-national advertising campaign. Therefore, Nike and Farah would be subject to the IOC Rule 40 guidelines if a similar campaign were planned for 2021. However, for national advertising campaigns, each individual country's NOC was deemed responsible for implementing its own version of Rule 40, while taking into consideration that country's specific applicable legal framework (Cleary Gottlieb, 2019; Pavitt, 2019). If Nike also launched a national advertising campaign in the UK featuring Farah in 2021, that campaign would be subject to the British Olympic Association (BOA) Rule 40 guidelines.

NOCs were permitted to adopt more flexible Rule 40 guidelines if desired or required under their national legal system. As each NOC supplemented the IOC Rule 40 guidelines, a clear pattern emerged where countries could be categorized as adopting a permissive approach (the Least Restrictive models), the IOC approach with only minor variations (the Moderate models), and an approach implementing a new personal sponsor contractual commitment process (USOC model). These three varied approaches also can be categorized on a spectrum from the least restrictive to the most restrictive (USOC model), with the majority 
of countries opting to adopt a moderate model with only slight variations from the IOC Rule 40. This variation is allowed so long as the NOCs' Rule 40 guidelines are consistent with five "key principles," which are discussed in the following section (IOC, n.d.a).

\section{A. IOC's Five "Key Principles"}

The IOC's five key principles distinguish between (1) sponsors (Olympic partners and non-Olympic partners); and (2) type of advertising permitted (generic, congratulatory messages, and online messages by athletes).

Olympic partners are permitted to use participant images without limitation, so long as they have the necessary contracts and permissions from the IOC, NOC, NGBs, or participants. Olympic partners are permitted to use the protected marks of the Olympic organizations and do not need to obtain any additional consent or provide notice of their upcoming marketing campaigns, other than as required in their sponsorship agreements. Olympic partners may engage in congratulatory advertising. Congratulatory advertising includes supporting messages and congratulatory messages. Supporting messages are messages encouraging, commiserating with, or otherwise supporting an athlete or national Olympic team. Congratulatory messages are messages praising an athlete or national Olympic team for achievements at the Olympic Games.

Non-Olympic partners may use participant images only (a) if they have the necessary consent from participants, (b) such use is consistent with any relevant policies of the NOCs, (c) such use does not use any protected Olympic marks, and (d) the advertising is generic advertising as described in the Rule 40 guidelines. In addition, non-Olympic partners must provide notice of their generic advertising plans by a date specified by the IOC or the NOC. IOC Rule 40 expressly states that "congratulatory advertising is not regarded as being generic because of the intrinsic connection with the Games" (IOC, n.d.a, p. 7).

Participants are restricted in how they can interact with their personal sponsors using their social media accounts or website. Participants may post "simple messages of thanks" on their personal website and social media accounts but their posts may not include any imagery from Olympic venues or protected Olympic IP. Their thank you messages also must not imply that the sponsor's product or service enhanced their performance; include any personal endorsement of the product or service; or relate to activities incompatible with the values of the Olympic movement or the NOC, such as tobacco, alcohol, gambling, and pornography. The participant's personal thank you messages also must not include images or videos of the athlete in his or her national Olympic team kit or with any Olympic medal (IOC, n.d.a). 
Consistent with the five key principles, each NOC developed its own Rule 40 guidelines for their nation's participants planned for implementation at the Tokyo 2020 Games. In this next section, we examine the least restrictive approach used by Germany and Great Britain and the moderate approach used by Australia and Canada.

\section{B. Least Restrictive Approach (Germany and Great Britain)}

Germany and Great Britain both made significant and substantive supplements to the IOC Rule 40 guidelines resulting in great freedom and flexibility for German and British Olympic athletes to promote themselves and their personal sponsors during the 2020 Olympics.

Germany's DOSB Rule 40 is the only NOC modification that does not require notification or approval by athletes or sponsors who are planning advertising campaigns during the Games (DOSB, 2019). Athletes and personal sponsors are encouraged to submit advertising campaigns for review and approval, but are not required to do so. German athletes and personal sponsors are also permitted to both continue existing marketing campaigns and create new campaigns during the Games period if desired, so long as those campaigns are otherwise consistent with the IOC marketing guidelines. Athletes may post an unlimited number of thank you messages so long as those messages do not use field of play imagery or share Olympic protected intellectual property. Personal sponsors may post an unlimited number of congratulatory messages between the sponsor and the athlete so long as the messages do not suggest the athlete's performance was connected to the use of the sponsor's products or services. German athletes are also expressly permitted to use terms and hashtags all other athletes are prohibited from using during the Games including: \#summergames2020 \#athletenameGames, Gold, Silver, Bronze, Medal, and the year or host city name (e.g., 2020 or Tokyo) so long as the year and host city are not combined (e.g., Tokyo2020). Lastly, violations of the German Rule 40 guidelines can only result in financial penalties to the athletes. DOSB may not impose sport-related sanctions on athletes, which would jeopardize their eligibility to compete. German athletes also may seek to resolve any disputes in the German court system rather than the DOSB or IOC grievance process (DOSB, 2019).

While the British Olympic Association (BOA) Rule 40 guidelines are not as permissive and flexible as the German guidelines, they still include several permissive elements that set them apart from other NOC modifications. First, athletes and personal sponsors have until June 30 to notify BOA of planned marketing campaigns, and may enter the marketplace as late as June 30 before the Games begin (BOA, n.d.). Athletes are expressly encouraged to use social media and 
photographic imagery of the Games to share their personal experience, so long as no sponsor mentions are included. While personal sponsors are still only permitted to post congratulatory messages before the after the Games period, athletes are permitted to post one thank you message per sponsor per event with a maximum of one post per sponsor per day and maximum of three posts per sponsor for the entire Games period. However, athletes are capped at an overall maximum of 10 personal sponsor thank you messages (BOA, n.d). This provides British athletes quite a bit of flexibility to strategize how best to use their maximum 10 personal sponsor thank you messages. If they only have two primary personal sponsors, they will be limited to six total thank you messages or three per sponsor, but if they have four or five personal sponsors they can decide how best to allocate their thank you messages under the BOA Rule 40 guidelines. The BOA Rule 40 guidelines do not expressly address sanctions or discipline for Rule 40 violations.

\section{Moderate Approach (Australia and Canada)}

The Australian Olympic Committee (AOC) and Canadian Olympic Committees (COC) adopted most of the IOC's Rule 40 guidelines with a few slight modifications. Both the AOC and COC adopted the IOC's generic advertising framework permitting "business as usual" campaigns featuring the sponsored athletes during the games (AOC, n.d.; COC, 2019). Business as usual campaigns are advertising campaigns that are already in the marketplace at least 90 days before the Games period begins and are not escalated during the Games. The $\mathrm{COC}$ and $\mathrm{AOC}$ also require notification by a specified fixed date and the advertising campaign must have been running for at least 90 days prior to the start of the Games period. Athletes and their sponsors may continue these advertising activities throughout the Games so long as they are generic, do not escalate the frequency or saturation of their advertising, and do not use any of the protected Olympic marks. The AOC excluded back-to-school campaigns as an example of acceptable continuing advertising that could occur during the Games period (AOC, n.d).

Consistent with IOC Tokyo Rule 40 guidelines, Australian and Canadian athletes may thank their sponsors for their support during the Games via social media and personal websites, so long as there is no commercial connection made between the Games and the sponsor, and the content of the message does not suggest the sponsor was responsible for the athlete's performance. Australia permits one thank you message per sponsor following each occasion a participant competes. Media reports suggested that this message could include a podium ceremony, but it is not specified in the AOC Rule 40 guidelines. Canadian 
athletes are only permitted one thank you message per sponsor regardless of the number of events or performances in which the athlete participates (COC, 2019).

Australian personal sponsors may only congratulate athletes for their achievements or performance before and after the games, but Canadian athletes' personal sponsors may post one congratulatory message and share one athlete thank you message, but the messages may not include photos or videos from the venues, team branded apparel, medals, or Olympic IP. Non-Olympic sponsors must notify the COC and AOC of their ongoing marketing campaign and their social media advertising plan, but that date for 2021 is yet to be determined. The detail required in the social media plan is not specified, but individual posts via social media do not need advance notice or approval, even though prior notice is recommended. Thus, presumably sponsors have some flexibility to create and adapt content in real time during the Games so long as it is consistent with the AOC and COC guidelines.

These four NOCs' Rule 40 guidelines reflect a consistent commitment to permitting a continuation of generic advertising, so long as that advertising does not escalate during the Games and the NOCs have been provided advance notice from the athlete and personal sponsor of the advertising campaign. Table 1 reports the similarities between all countries evaluated for this paper.

The greatest area of differentiation among the Least Restrictive Models and the Moderate Models is (a) when and whether notification and registration of personal sponsors is required, (b) the number of thank you messages permitted by athletes, and (c) whether sport-related sanctions can be imposed on an athlete for a violation by a personal sponsor. Consistent among all models is the prohibition on the athlete from using imagery that includes any Olympic field of play scenes, Olympic venues, national team apparel, or protected intellectual property of the Olympic organizations. Messages that are permitted must not contain any promotion of the sponsor's products or services and must take care to avoid messaging attributing the athlete's performance to the sponsors' products or services.

In the next section, the more restrictive model, as reflected in the USOPC's Rule 40 guidelines, is presented and critiqued. The USOPC, together with Ireland and South Africa, have introduced another layer of control over national advertising campaigns in the form of a personal sponsor commitment (PSC) agreement in which (a) the athlete must register all personal sponsors; and (b) the personal sponsors must agree to comply with a PSC in order to be eligible for Rule 40 permissive advertising and marketing activities sanctioned by IOC Rule 40 (OFI, n.d.; SASCOC, 2020; USOPC, 2019a). This more restrictive paradigm and the contractual requirements of the PSC are explored in the next section. 


\begin{tabular}{|c|c|c|c|}
\hline 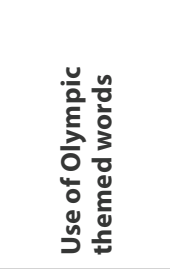 & & 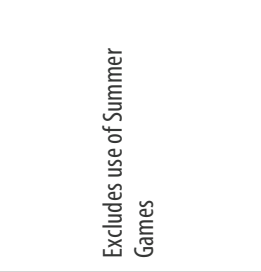 & 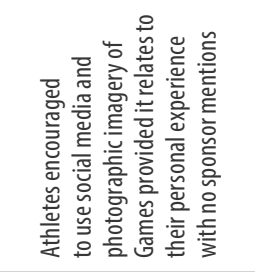 \\
\hline 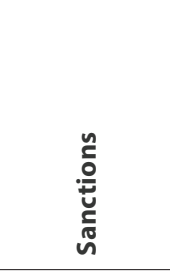 & 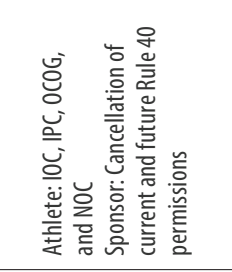 & 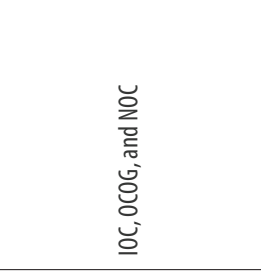 & 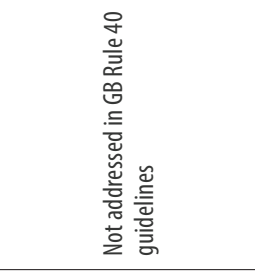 \\
\hline 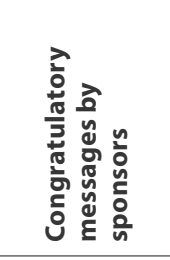 & 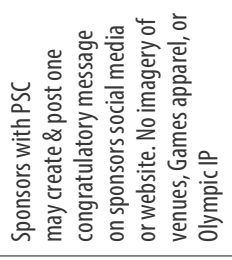 & 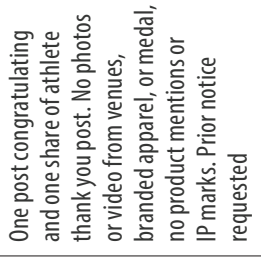 & 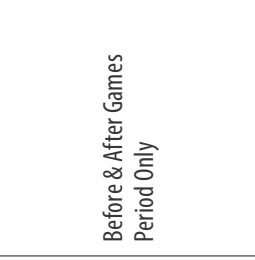 \\
\hline 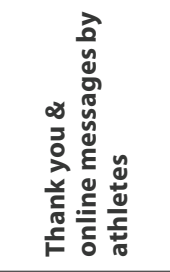 & 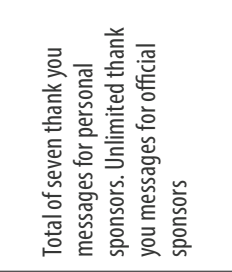 & 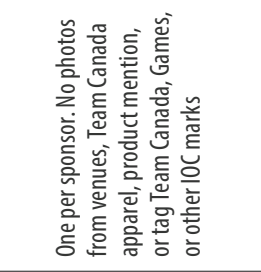 & 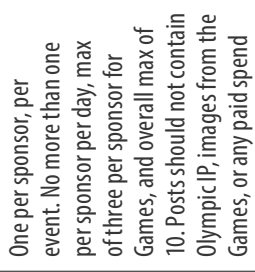 \\
\hline 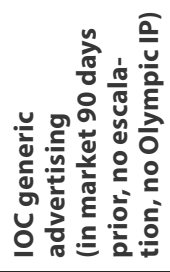 & 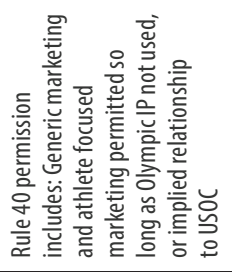 & 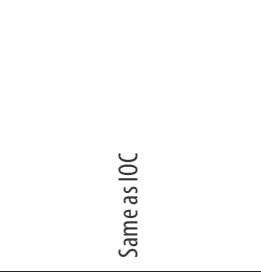 & 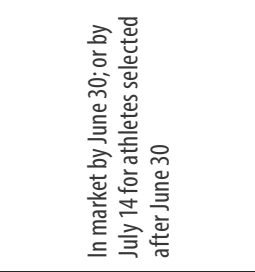 \\
\hline 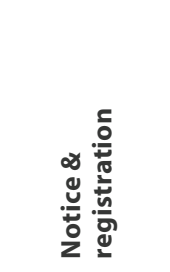 & 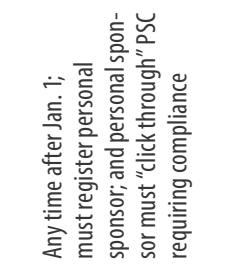 & $\stackrel{\frac{n}{\pi}}{\sum_{z}^{\frac{\pi}{2}}}$ & 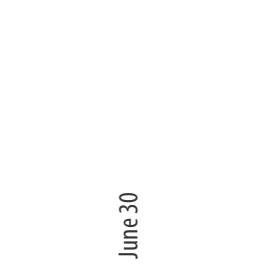 \\
\hline 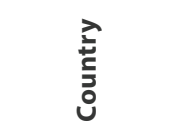 & $\stackrel{*}{\sim}$ & $\begin{array}{l}\text { 茔 } \\
\text { 芯 }\end{array}$ & 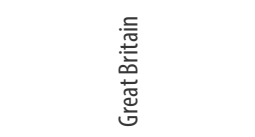 \\
\hline
\end{tabular}




\begin{tabular}{|c|c|c|c|c|}
\hline & & 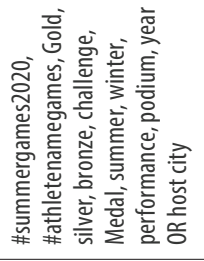 & & 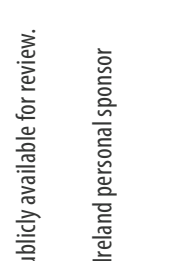 \\
\hline 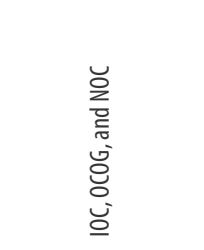 & 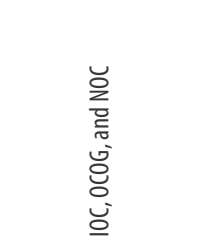 & 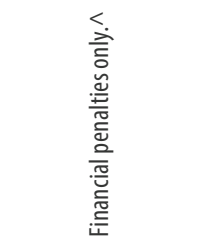 & 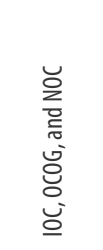 & 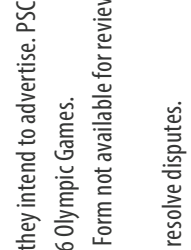 \\
\hline 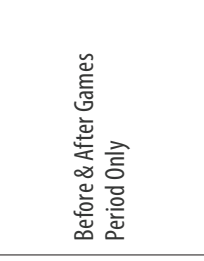 & 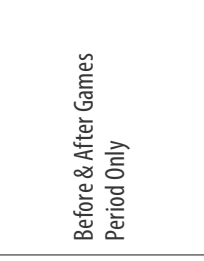 & 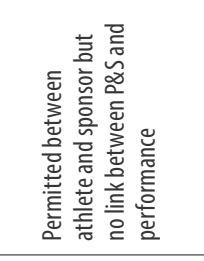 & 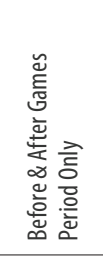 & 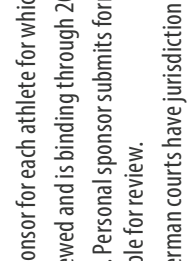 \\
\hline 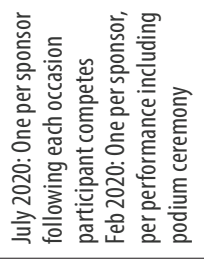 & 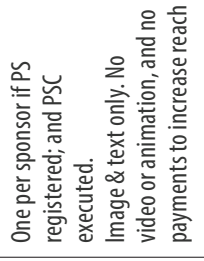 & 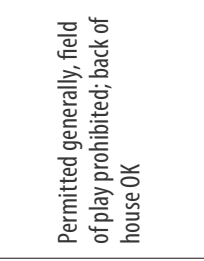 & 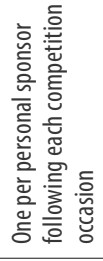 & 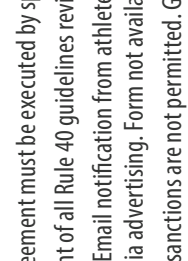 \\
\hline 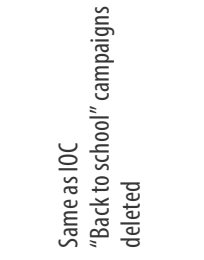 & 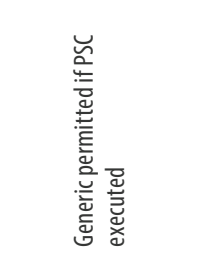 & 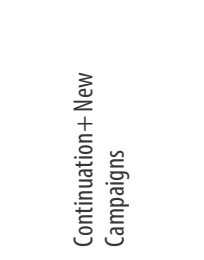 & & 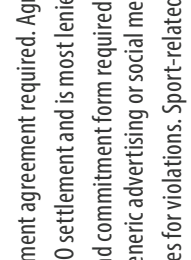 \\
\hline$\stackrel{\frac{n}{2}}{\underset{\pi}{\pi}}$ & 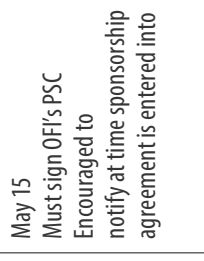 & $\begin{array}{l}\text { 嶂 } \\
\text { 言 }\end{array}$ & 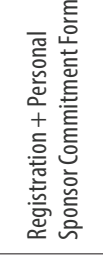 & 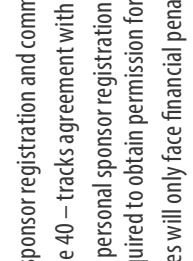 \\
\hline 焉 & 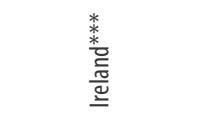 & 荵 & 豆蒡莫 & 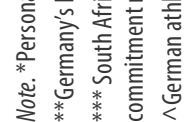 \\
\hline
\end{tabular}




\section{USOPC Adopts a New Contractual Paradigm to Enforce Rule 40}

In October 2019, the USOPC unveiled its new guidance for Rule 40, much of which mimicked the provisions of those proffered by the other countries previously discussed. The guidance permitted athlete personal sponsors to use the name, image, voice, likeness, and signature of an Olympic participant for marketing purposes during the Tokyo Games blackout period in two types of advertising: (1) non-Olympic Games-related generic advertising and (2) athletefocused advertising, as long as it was limited to a personal sponsor making one congratulatory social media post per sponsored athlete and the sponsored athlete making up to seven social media posts thanking his/her personal sponsors (Chase, 2020).

\section{A. Overview of the USOPC Approach to Rule 40 Enforcement}

The USOPC approach (also subsequently adopted in Ireland and South Africa) differs from that of the majority of countries in one significant way. Its permission system includes a two-step process requiring the athlete to register his/her personal sponsors with the USOPC and requiring the personal sponsor to agree to be bound by a PSC agreement (Chase, 2020). This contractual mechanism affords the USOPC the ability to sue the athlete's personal sponsor for breach of contract, seek contractual damages, seek injunctive relief, and otherwise hold the sponsor to certain restrictive obligations designed to prevent the ambush marketing of the Olympics and its official sponsors. By creating a contractual relationship between the USOPC and the personal sponsor, the PSC and the provisions within the PSC afford the USOPC much greater protections than it previously had under intellectual property laws such as the Lanham Act, Ted Stevens Olympic \& Amateur Sports Act, and U.S. copyright law. The next section examines several legal concerns related to the interpretation and scope of the PSC.

\section{B. Legal Concerns Raised in the USOPC Personal Sponsor Commitment Agreement}

Initial legal concerns relate to the interpretation and application of the terms and conditions the USOPC has included in the PSC. This section examines key sections of the PSC to identify vague or ambiguous provisions that could be subject to multiple or inconsistent interpretations between the parties. Thereafter, legal questions that may be raised regarding the enforceability of the PSC will be examined. 


\section{Interpretation and Application of the Personal Sponsor Agreement}

What might be considered the "preamble" seeks to position the agreement merely as a unilateral benefit to the athlete:

This Agreement represents each of APS's [Athlete Personal Sponsors'] and the USOPC's commitment to empowering athlete to support and celebrate their careers, without infringing on or diluting the longstanding rights afforded to Olympic, Paralympic and National Organizing Committee ("NOC") partners and sponsors. APS and the USOPC understand and acknowledge the importance of the Agreement ... They further recognize that this Agreement is intended to prevent APS and the athletes they support from breaching - intentionally or inadvertently - Olympic Charter bye-law 40.3 which could impact the athletes' Games eligibility and/or carry other consequences. (USOPC, 2019, p. 1)

This language, positioned perhaps as advisory representations, obscures the true nature of the agreement that imposes numerous obligations on athletes and personal sponsors not required by IOC Rule 40. First, the PSC seeks to contractually prevent personal sponsors from using a wide range of marks, words, and images associated with U.S. Olympic organizations, including protected trademarks, such as the Olympic rings symbol and trademarked words and phrases including "Games," "Tokyo 2020," "Go for the Gold," and "Let the Games Begin." The PSC also asserts exclusivity for Games emblems, emojis, iconic Olympic imagery (such as a torch, flame, laurel wreath, medal, or podium), Team USA or Games-branded apparel, or photographs or videos from any Olympic Games. According to the PSC, none of the aforementioned marks, words, or emblems may be used in any marketing campaign featuring a sponsored athlete. Furthermore, the PSC incorporates the "business as usual" requirements from the IOC Tokyo Rule 40 framework, but includes these limitations as part of the contractual commitment of the personal sponsor rather than the guidelines for which personal sponsors should navigate to avoid potential impermissible activities. According to the PSC, the personal sponsor agrees that its marketing campaign using the athlete,

should where possible, (i) be representative of a continuous campaign and an extended relationship between the APS and Athlete, and (ii) not increased in frequency or substantially changed during the Applicable Games Period as to prior campaigns within the Games year and/or the same period in a non-Games year. (USOPC, 2019, p. 3)

Paragraph D of the PSC states that the "APS expressly commits that its Campaigns will not imply any relationship between APS or any of its products/ 
services and Team USA, an NGB, the IOC, the IPC, the Olympic or Paralympic Games, or the Olympic or Paralympic Movement" (USOPC, 2019, p. 3).

The PSC also contains a number of other provisions that integrate illustrative guidance elements from IOC Rule 40 as formal contractual commitments for personal sponsors of U.S. athletes. The following provisions are included in the PSC:

- APS must not engage in paid advertising to support retweets or reposts of Athlete "thank you" messages;

- APS must not combine its sponsored athletes in its advertising and marketing campaigns;

- APS Campaigns will not make negative, comparative claims;

- APS Campaigns will not imply that any product or service enhanced an Athlete's Games performance;

- APS will not use the terms: Games, Winter Game or Summer Games to refer to the Olympic or Paralympic Games;

- APS will not use iconic Olympic or Paralympic words or imagery such as a torch, flame, laurel wreath, medal or podium;

- APS will identify and provide USOPC a single point of contact for efficient and effective investigation and resolution of matters related to this Agreement. (USOPC, 2019, p. 4)

The PSC also adopts a category of permissive advertising referred to as "Athlete-focused Advertising" and defines Athlete-focused Advertising as "a piece of content that includes the Likeness of an Athlete, solely in the form of (a) an athlete thanking an APS, or (b) APS recognizing an athlete's personal story (i.e. congratulatory or well-wishing messaging)" (USOPC, 2019, p. 2). Athlete-focused Advertising presumably is the USOPC's umbrella term for "congratulatory messages" and "athlete thank you messages" under the IOC Rule 40 guidelines. However, the PSC has a conflicting definition of Athlete-focused Advertising from how such activities are defined in the USOPC Rule 40 guidance. The guidance defines Athlete-focused Advertising as any content that includes the likeness of an athlete including, name, image, or voice. Under the PSC, content is only Athlete-focused Advertising if it is an athlete thank you message or personal sponsor congratulatory message. Using this context, the PSC further requires the personal sponsor to agree that Athlete-focused Advertising will not engage in any of the following: a) include the likeness of more than one athlete; b) mention or promote personal sponsor products or services; c) contain the likeness of more than one athlete or more than one mention of the personal sponsor brand, name, or logo; or d) support messages with paid advertising. 
Similarly, the termination provisions provide the USOPC with expanded contractual remedies as a supplement to currently available legal remedies for alleged violations of the IOC or USOPC Rule 40 guidelines. The "breach of agreement" provision states that "[a]ny violation of any provision hereof, any misrepresentation made hereunder, any material nondisclosure or omission of any material fact, or any failure to perform any obligation of APS will constitute a breach of the Agreement ... [and] the APS will bear the liabilities arising from such breach ..." (USOPC, 2019, p. 4). These liabilities include "immediate cancellation of all current Rule 40 permission for all APS athletes" and the "inability to obtain further Rule 40 permissions for the next two Games (i.e. Olympic Winter Games Beijing 2022 and Olympic Games Paris 2024)" (emphasis added). Of particular concern here first is lack of clarity in that the agreement does not identify or specify who decides or how a determination is made as to whether the personal sponsor has violated a provision of the PSC. Thus, it is unclear if the USOPC can unilaterally make such a determination and unilaterally exercise the cancellation rights contained in the PSC. The PSC does not include any dispute resolution provisions. A second concern is the breadth and duration of the penalty for an alleged violation. For example, in terms of breadth, a personal sponsor could inadvertently share one athlete's thank you post via social media, and according to the PSC, all advertising permissions of the personal sponsor for every athlete that company supports could be canceled. This could impact a personal sponsor's significant financial investment in ongoing advertising campaigns for which it is already contractually obligated across multiple advertisement platforms. In terms of duration, that same inadvertent act would also simultaneously prohibit the personal sponsor from obtaining permissions for four years through the next two Olympic Games.

This "breach of agreement" provision has elements similar to those found in restrictive covenants designed to limit the actions of one party after the contractual relationship has ended. A restrictive covenant is a promise included in a contract or agreement that somehow restricts one of the parties from doing something. Although restrictive covenants, most commonly used in employment contracts, are legal, in some cases courts have invalidated specific aspects, most notably when restrictions are particularly exacting or limit the ability of the restricted party to do business (Brodsky, 2019). Governed by state law, the majority of states assess restrictive covenants based on a "reasonableness" test. Applying this fact-specific test to the SPC agreement, a court would assess if: (1) its terms are no greater than is required to protect USOPC's legitimate business interests; (2) it would not impose an undue hardship on the APS; and (3) it is not injurious to the public (Brodsky, 2019). Generally, restrictive covenants will be deemed 
unenforceable if they are not drafted narrowly in terms of scope, geographic area, and time period. Assuming, arguendo, that a court was to determine that the SPC itself is an enforceable contract, it could nonetheless hold that the SPC's rather punitive "two Games period" restriction fails the reasonableness test.

The final concern arising in the "breach of agreement" provision relates to the admonition to the personal sponsor through an acknowledgment section wherein the personal sponsor must expressly acknowledge and agree that failure to comply with the agreement or the USOPC guidance may jeopardize the athlete's eligibility to participate in the Games. This is a significant departure from the German model. The German model expressly limits DSOB's remedies to financial sanctions against athletes and gives the athletes a right to have such sanctions reviewed in the German court system and is also more heavy handed than the Moderate Models. For example, the Canadian approach says:

Athletes for Team Canada are bound by the provisions of the Olympic Charter, including Rule 40 . While it is the responsibility of each athlete to comply with Rule 40 and these guidelines, any sponsor using a Team Canada athlete for advertising purposes ... will want to ensure they are not putting the athlete in breach of Rule 40. Athletes who do not comply with Rule 40 and these guidelines may be sanctioned by IOC, Tokyo 2020, and/or COC. (COC, 2019, p. 14)

While the Canadian Rule 40 guidelines acknowledges sanctions are possible, eligibility is not expressly asserted as the type of sanction for which an athlete or personal sponsor should be concerned.

Another area of concern relates to the underlying enforceability of the agreement and potential flaws in the formation of the contract. A contract is "a promise, or set of promises, for breach of which the law gives a remedy, or the performance of which the law in some way recognizes a duty" (Restatement [Second] of Contracts, 1981, §1). The formation of a contract has four fundamental elements: 1) agreement through an offer and acceptance; 2) consideration; 3) capacity, and 4) legality. While the PSC meets the capacity and legality elements, the first two elements are less clear.

Several issues arise as to whether an enforceable contract has been formed. Typically, a contract entails a "mutual meeting of the minds" attained through a process of negotiation. The PSC, however, is not an offer and acceptance derived through a negotiation. It is a "take it or leave it" proposition. There is no opportunity for the personal sponsor to negotiate different terms or conditions. Additionally, the parties must convey their mutual assent to be bound by the terms of the contract. However, the USOPC Rule 40 guidelines themselves describe the personal sponsor's commitment as a "click through" assent to be sent via email. The legality of "click through" for the online sale of products 
and services is permissible, but at a minimum should include an opportunity to review the terms, display of the terms, rejection of terms and its consequences, assent to terms, opportunity to correct errors, and keeping record to prove assent (Feldman, 2019; Schreiber, 2019-20). Indeed, the use of "click through" agreements is typically associated with a user accessing services of an online provider according to the terms and conditions of that web-based service provider, such as Ticketmaster (Kar \& Radin, 2019).

In this situation, the USOPC is not providing online services for personal sponsors. The licensing or marketing rights the USOPC suggests it is providing to the personal sponsors are already available without entering into a "click wrap" PSC agreement. Some cases have challenged whether the requisite assent to form a contract is present in a "click through" or "click wrap" agreement. Some courts have also required that a rejection of the terms must prevent the user from completing the transaction and accessing the services provided (Register. com, Inc. v. Verio, Inc., 2004; Bragg v. Linden Research, Inc., 2007). To apply that logic to the USOPC's "click through" PSC, a rejection by the USOPC would not prevent the personal sponsor from continuing to undertake any permissible advertising activities consistent with current intellectual property and false advertising laws. The only consequence of a rejection is the threat of punishment of the athlete through denial of eligibility or the opportunity to participate, which has nothing to do with any underlying services offered by the USOPC to the personal sponsor. Furthermore, one can argue that the PSC is an example of a disparity of bargaining power, in much the same way that commentators have asserted that the National Letter of Intent (NLI) used in college athletics constitutes a disparity of bargaining power (Meyer, 2004).

Another question relates to whether there is valid consideration and whether the personal sponsor's promise is illusory or unconscionable, because it grants too much discretion and control to the USOPC (Bar On, 2019). While defenses based on lack of consideration, illusory promises, and unconscionability are fraught with many exceptions, these are still concerns that could undermine the validity of the PSC (White, 2020). The PSC states: "For good and valuable consideration, the receipt of which is hereby acknowledged, the parties agree as follows, intending to be legally bound ..." But what is the "good and valuable" consideration that the USOPC providing? According to the PSC, the USOPC expressly commits to the following:

- Support and implement the Guidance throughout each applicable Games Periods in the United States;

- Provide the opportunity for athletes and APS to engage in educational opportunities including but not limited to: group information sessions, individual discussion with USOPC athlete marketing representatives, as well as access to specific materials regarding the 
background of Olympic and Paralympic marketing and implementation of the Guidance; and

- Provide review of Campaign materials for guidance compliance upon the request of the APS.

All of these activities first have questionable "value" to the APS and more importantly are arguably already included among the statutorily mandated duties of the USOPC consistent with its federal charter under the Ted Stevens Olympic and Amateur Sports Act of 1998 (OASA). One can also argue that the personal sponsor is offered the right to engage in marketing activities during the black-out period that they already possess, provided they do not infringe on the IOC's or USOPC's intellectual property rights.

Lastly, is the omission of what should be carefully crafted provisions addressing performance requirements and how to resolve disputes or misunderstandings. As mentioned previously, the PSC is silent as to dispute resolution. The only reference to disputes is in the form of the personal sponsor agreeing to provide a single point of contact for the efficient and effective investigation and resolution of matters related to the agreement. It is noteworthy that the USOPC does not have a reciprocal provision wherein it agrees to provide the personal sponsor or athlete a single point of contact in order to resolve disputes. The PSC also does not specify who at the USOPC or other entity will be responsible for tracking and "counting" the number of personal sponsor posts across the potential of hundreds of athletes, as well as ensuring that they are not re-tweeted or boosted by APS advertising. The PSC is silent as to many areas that are critical to the expressed contractual obligations of the personal sponsors including: a) what is the procedure within the USOPC for determining if a personal sponsor post "implies any relationship" with the Olympics or "implies" that a product or service enhanced an athlete's performance?; b) what is the process for determining if a personal sponsor's marketing campaign has "increased in frequency or substantially changed" during the Games?; c) who is responsible for tracking the number and content of thank you and congratulatory messages?; d) are both negative and comparative claims prohibited, comparative to what, or just comparative claims that are negative?; and e) who decides whether an advertisement includes negative or comparative claims as those terms are not defined in the agreement (McKelvey, Grady, \& Moorman, 2020).

Overall, there are a number of legal concerns regarding the meaning and scope of the PSC and its underlying enforceability as a validly executed contractual agreement. These concerns create significant practical concerns for personal sponsors and athletes who try in good faith to comply with the IOC Rule 40 and the key principles. 


\section{Practical Concerns Raised by the Personal Sponsor Commitment Agreement}

If a company chooses to push the envelope and market around the grey areas (whether the marketing be dubbed ambush marketing or not), that is their prerogative. Indeed, as one noted agent pointed out, there have been hundreds of instances during the past few Olympics where companies have engaged in marketing of their endorsee athletes, without any repercussions (P. Carlisle, email communication, Feb. 3, 2020).

The restrictions posed on the free speech rights of the personal sponsor further muddle the practical viability of the SPC document that, when executed, allows for a personal sponsor to tweet phrases such as "Congratulations @athlete on your personal best. \#silver" or "Go get 'em, @athlete. \#USA" (USOPC, 2019, p. 6). Conversely, the USOPC rules state that phrases such as the following not be permitted: "Today's your day to shine @athlete \#Team[company]," "Congratulations@athlete. [Company slogan]" or "Congratulations@athlete on your Olympic gold medal" (USOPC, 2019, p. 6). One can argue, however, that personal sponsors would have a First Amendment right, within the scope of current commercial speech doctrine set forth in Bolger v. Youngs Drug Corp. (1983) and its progeny, to tweet any of these phrases without the contractual approval of the USOPC (see Grady \& McKelvey, 2018, which examines this issue in the context of HSK LLC, d.b.a. Zerorez v. United States Olympic Committee, 2016).

At least one prominent agent for Olympic athletes feels the SPC should be ignored:

"The Personal Sponsor Commitment agreement purports to provide non-sponsor companies with all these rights that they already have in the first place. Legally, sponsors have always had the right to say "thank you" and "congratulations, so long as they don't use Olympic marks. The only recourse the USOPC has, and has always used as the hammer, is the threat of removal of the athlete from competition, which they have never done and which they should never do, as it would violate the most fundamental principles of Olympism. This is why the USOPC is now pressuring the athletes to push their sponsors to agree to restrictions that wouldn't otherwise exist. Ironically, we have always advised both athletes and sponsors to comply with Rule 40, not because we believe it's justified, or even enforceable, but because it's the only way to insulate the athletes from the USOPC's disruptive, heavy-handed enforcement tactics, which they employ at the very moment these athletes have been preparing for most of their lives, during the Games." (P. Carlisle, email communication, June 15,2020 ) 


\section{Conclusion}

The evolution of Rule 40 over the past several years, prompted by nearly a decade of athlete and agent discontent and ultimately triggered by the German Cartel Office's Commitment Decision between the IOC and the DOSB, has expanded the opportunity for athletes to benefit from their relationships with companies and brands who are not official sponsors of the various Olympics-related governing bodies. However, in contrast to the other countries that have made their revised Rule 40 guidelines publicly available, the USOPC has gone further than any in seeking to "have their cake and eat it too"- to condition marketing opportunities for its U.S. athletes upon a personal sponsor's acceptance of contractual terms and conditions far more restrictive than sponsors situated in other countries. This approach has the potential to diminish vital financial support for Olympic and Paralympic athletes derived from personal sponsors under the questionable justification of maintaining excessive control over ambush marketing activity of non-official Olympic sponsors.

While the creation of the PSC process is a clever mechanism for controlling ambush marketing through contract law, the contract as presented to personal sponsors arguably places them in an untenable situation of not only putting their sponsored athletes at risk by violating the contract, but also agreeing to curtail marketing activities that they otherwise would have the legal right to do. As previously examined, the PSC is not without its flaws, some of which may be fatal to the enforceability of the document as a "contractual agreement between the parties." It remains to be seen how the PSC process will play out in advance of the Tokyo Games in 2021, including how many brands will actually choose to participate in the USOC Rule 40 PSC process and execute the agreement.

\section{References}

Australian Olympic Committee. (n.d.). Key principles incorporating AOC Supplementary Guidelines for Australian participants. AOC. Retrieved from https://www.olympics.com.au/resources/ articles/athlete-guidelines/

Bar On, A. E. (2019). Unconscionability 2.0 and the IP boilerplate: A revised doctrine of unconscionability for the information age. Berkeley Technology Law Journal, 34, 567-703.

Behagen v. Amateur Basketball Ass'n of the United States, 884 F.2d 524 (10th Cir. 1989).

Belson, K. (2012, July 30). Olympians take to Twitter to protest endorsement rule. New York Times. Retrieved from https://www.nytimes.com/2012/07/31/sports/olympics/athletes-at-olympics-protest-sponsorship-rule-on-twitter.html

Blevins, J. (2014, Jan. 27). Olympic athletes adjust to rules forbidding them from open sponsorship. The Denver Post. Retrieved from https://www.denverpost.com/2014/01/27/olympic-athletes-adjust-to-rules-forbidding-them-from-open-sponsorship/

Bolger v. Youngs Drug Corp., 463 U.S. 60 (1983). 
Bradish, C., Koehler, R., \& Bailey, A. (2019) Olympic commercialization and player compensation: A review of financial reports. Retrieved from https://mcusercontent. com/84af2d82b4ff06bd42452dbf8/files/39f1fd06-9ec8-4ca3-85b1-a9d392aefaad/2020.04.22 Olympic_Commercialization_and_Player_Compensation_FINAL.pdf

Bragg v. Linden Research, Inc., 487 F.Supp.2d 593 (E.D. Pa. 2007).

Brodsky, S. L. (2019, Feb. 8). Restrictive covenants in employment and related contracts: Key considerations you should know. ABA.com. Retrieved from https://www.americanbar.org/ groups/litigation/committees/commercial-business/practice/2019/restrictive-covenants-employ$\underline{\text { ment-related-contracts/ }}$

British Olympic Association. (n.d.). Rule 40 - Summary for Team GB athletes. BOA. Retrieved from http://www.teamgb.com/docs/default-source/boa-legal/rule-40---summary-for-team-gbathletes.pdf

Butler, N. (2017, Oct. 28). German competition authorities challenge DOSB over Rule 40 marketing restrictions. Inside the Games. Retrieved from https:/www.insidethegames.biz/ articles/1057224/german-competition-authorities-challenge-dosb-over-rule-40-marketing-restrictions

Canadian Olympic Committee. (2019). Athlete marketing/Rule 40 guidelines for athletes and personal sponsors - Tokyo 2020. COC. Retrieved from https://olympic.ca/wp-content/uploads/2020/01/athlete-marketing-rule-40-guidelines tokyo2020-pdf

Chanavat, N., \& Desbordes, M. (2014). Towards the regulation and restriction of ambush marketing? The first truly social and digital mega sport event: Olympic Games, London 2012. International Journal of Sports Marketing \& Sponsorship, 15(3), 151-160. https://doi.org/10.1108/ IJSMS-15-03-2014-B002

Chase, C. (2020, Jan. 21). Permissions system for Rule 40 open for Olympic participants and brands. Lexology.com. Retrieved from https://www.lexology.com/library/detail.aspx?g=dbac6e2f-ae66-416d-8312-38e2b34d77a5

Clark, O. (2016, August 1). Brazil enacts new ambush marketing laws. Osborne Clark. Retrieved from https://marketinglaw.osborneclarke.com/marketing-techniques/brazil-enacts-new-ambush-marketing-laws/

Cleary Gottlieb (2019, January-February). FCO ends probe into organization and marketing of Olympic Games with Commitment Decision. German Competition Law Newsletter. Retrieved from https://www.clearygottlieb.com/-/media/files/german-competition-law-newsletters/german-competition-newsletterjanfeb2019-pdf.pdf

Cohen, K. (2020, March 24). Tokyo 2020 Olympics officially postponed to 2021. ESPN.com. Retrieved from https://www.espn.com/olympics/story//id/28946033/tokyo-olympics-officially-postponed-2021

Deutscher Olympischer Sportbund. (2019, February 26). Advertising opportunities and restrictions during the Olympic Games: Rule 40 and social media. DOSB. Retrieved from https:// www.wfsgi.org/system/files/2019-10/2019-02-26_Rule40_GER\%20\%28003\%29.pdf

Deutscher Olympischer Sportbund (DOSB) e.V. Otto-Fleck-Schneise (2019, Feb. 29) Bundeskartellamt Decision B2 - 26/17. Retrieved from https://www.bundeskartellamt.de/SharedDocs/ Entscheidung/EN/Entscheidungen/Missbrauchsaufsicht/2019/B2-26-17.pdf? blob=publicationFile \& $v=2$

Ellis, D. Scassa, T., \& Séguin, B. (2011). Framing ambush marketing as a legal issue: An Olympic perspective. Sport Management Review, 14(3), 297-308. https://doi.org/10.1016/j. $\underline{\text { smr.2011.02.002 }}$ 
Epstein, A. (2017). The ambush at Rio. The John Marshall Review of Intellectual Property Law, 16, 350-381. Retrieved from https://repository.jmls.edu/cgi/viewcontent.cgi?article=1415\&context=ripl

FCO Case Summary. (Case No: B2-26/17). Decision in administrative proceeding DOSB et al. (2017).

Feldman, S. W. (2019, Summer). Actual agreement, shared meaning analysis, and the invalidation of boilerplate: A response to Professors Kar and Radin. Missouri Law Review, 84, 711-778. https://doi.org/10.2139/ssrn.3336377

Fischer, B. (2016, July 27). Ringing endorsement: Olympic blackout period for non sponsors goes into effect today. Retrieved from https://www.sportsbusinessdaily.com/Daily/Issues/2016/07/27/Marketing-and-Sponsorship/Oly-Rule-40.aspx

Fischer, B. (2019, October 8). USOPC makes major changes to "Rule 40" on sponsorship. Retrieved from https://www.sportsbusinessdaily.com/Daily/Morning-Buzz/2019/10/08/Rule-40. aspx

Given, K. (2016, August 19). Wbur.com. Rule 40: Why companies can't say 'Summer' during the Olympics. Retrieved from https://www.wbur.org/onlyagame/2016/08/19/olympic-ads-social$\underline{\text { media-rule-40 }}$

Gold Medal, LLC. v. USA Track \& Field, 187 F. Supp. 3d 1219 (D. Or. 2016).

Gold Medal, LLC. v. USA Track \& Field, 899 F.3d 712 (9th Cir. 2018).

Grady, J. (2016). Predicting the future for Rio 2016: Legal issues in sponsorship, ambush marketing, and social media. Entertainment and Sports Law Journal, 14(2), 1-4. https://doi. org/10.16997/eslj.199

Grady, J. (2017). Analyzing Rule 40's restrictions on using athletes in Olympic sponsorship at Rio 2016. Entertainment and Sports Law Journal, 15(1), 1-5. https://doi.org/10.16997/eslj.205

Grady, J. (2021). Legal aspects of the Olympics and ambush marketing. In D. Chatziefstathious, B. Garcia, \& B. Seguin (Eds.), Routledge handbook of the Olympic and Paralympic Games (pp. 130-138). Routledge: New York/London. https://doi.org/10.4324/9780429440311-15

Grady, J., \& McKelvey, S. (2018). Congratulations but \#SeeYouInCourt: Olympic hashtag restrictions raise concerns over trademark rights and free speech. Harvard Journal of Sport and Entertainment Law. 9(2), 101-130. Retrieved from https://harvardjsel.com/wp-content/uploads/ sites/9/2018/06/HLS203.pdf

Grady, J., \& McKelvey, S. (2015, May 18). The IOC's Rule 40 changes and the forecast for Rio 2016. Retrieved from https://www.sportsbusinessdaily.com/Journal/Issues/2015/05/18/Opinion/ Grady-McKelvey.aspx

Grady, J., \& McKelvey, S. (2012). Ambush marketing lessons from the London Olympic Games. Sports Business Journal. Retrieved from http://www.sportsbusinessdaily.com/Journal/Issues/2012/10/22/Opinion/Grady-McKelvey.aspx

Grady, J., \& Moorman, A. (2018). Rule 40 versus European competition laws: A new challenge to an ongoing sponsorship concern. European Association for Sport Management conference: Bern, Switzerland.

HSK LLC, d.b.a. Zerorez v. United States Olympic Committee, No: 16-civ-02621-WMW-KMM (D. Minn. Aug 4, 2016).

International Olympic Committee. (2019, June 26). Olympic Charter. Retrieved from https:// stillmed.olympic.org/media/Document\%20Library/OlympicOrg/General/EN-Olympic-Charter. pdf 
International Olympic Committee. (n.d.a). Commercial opportunities for participants during the Tokyo 2020 Olympic Games. Retrieved from https://d2g8uwgn11fzhj.cloudfront.net/wp-content/uploads/2020/02/26153147/Commercial-opportunities-for-Participants-during-the-Tokyo-2020-Olympic-Games.pdf

International Olympic Committee. (n.d.b). Use of a participant's image for advertising purposes during the Rio 2016 Olympic Games. Retrieved from https://stillmed.olympic.org/Documents/ Athletes Information/Rule 40-Rio_2016-QA for_Athletes.pdf

International Olympic Committee. (n.d.c). Commercial opportunities for participants Olympic Games Tokyo 2020: Illustrative guidance for non-Olympic partners. Retrieved from https:// d2g8uwgn11fzhj.cloudfront.net/wp-content/uploads/2020/03/06094714/Commercial-Opportunities-For-Participants_Oympic-Games-Tokyo-2020_Illustrative-Guidance-For-Non-Olympic-Partn.pdf

JES Props., Inc. v. USA Equestrian, Inc., 458 F.3d 1224 (11th Cir. 2006).

Kar, R. B., \& Radin, M. J. (2019, February). Pseudo-contract and shared meaning analysis. Harvard Law Review, 132, 1135-1219. https://doi.org/10.2139/ssrn.3072817

Li, S. (2016, August 11). Olympics bans most brands from saying 'Olympics' or 'Rio,' even on Twitter. Snark ensues. Los Angeles Times. Retrieved from https://www.latimes.com/business/ la-fi-olympics-rule-40-20160802-snap-story.html

Louw, A. M. (2012). Ambush marketing and the mega-event monopoly: How laws are abused to protect commercial rights to major sporting events. Asser Press: The Hague, Netherlands.

McKelvey, S., \& Grady, J. (2008). Sponsorship program protection strategies for special sport events: Are event organizers outmaneuvering ambush marketers? Journal of Sport Management, 22(5), 550-586. https://doi.org/10.1123/jsm.22.5.550

McKelvey, S., Grady, J., \& Moorman, A. J. (2020). A trans-national analysis of new IOC Rule 40 guidance and subsequent enforcement challenges to Olympic advertising and sponsorship restrictions. Presented at 32nd Sport and Recreation Law Association conference (Louisville, KY, March 4, 2020).

McKelvey, S., \& Longley, N. (2015) Event-specific ambush marketing legislation for mega-sporting events: An economics perspective. International Journal of Sport Marketing \& Sponsorship, 16(5), 349-364. https://doi.org/10.1108/IJSMS-16-05-2015-B003

Meyer, S. (2004). Unequal bargaining power: Making the National Letter of Intent more equitable. Marquette Sports Law Review, 15(1), 227-247.

Nakamura, B. M. (2018). Is Olympic ambush marketing here to stay? Examining the issues surrounding ambush marketing as they related to Olympic sponsors, athletes, and other stakeholders. Arizona Journal of International \& Comparative Law, 35, 500-529.

Olympic Federation of Ireland. (n.d.). Commercial opportunities for participants during the Tokyo 2020 Olympic Games incorporating OFI supplementary guidelines. OFI. Retrieved from https://olympics.ie/wp-content/uploads/2020/02/Team_Ireland_Rule_40_Guidelines.pdf

Pavitt, M. (2019, April 21). No clear cut solution to Rule 40 and athlete representation debates. Inside the Games. Retrieved from https://www.insidethegames.biz/articles/1078230/michaelpavitt-no-clear-cut-solution-to-rule-40-and-athlete-representation-debates

Quack, S., \& Djelic, M. (2018). Adaptation, recombination and reinforcement: The story of antitrust and competition law in Germany and Europe. In W. Streeck \& K. Thelen. Beyond continuity (pp. 255-281). Oxford University Press. Retrieved from https://hal.archives-ouvertes.fr/ $\underline{\text { hal-01892003/document }}$

Register.com, Inc. v. Verio, Inc., 356 F.3d 393 (2nd Cir. 2004). 
Reynolds, T. (2012, July 30). Some Olympians want marketing rules changed. Retrieved from https://www.nydailynews.com/sdut-some-olympians-want-marketing-rules-changed-2012jul30story.html

Rovell, D. (2016, July 21). USOC sends letter warning non-Olympic sponsor companies, ESPN. Retrieved from http://www.espn.com/olympics/story/_id/17120510/united-statesolympic-committee-battle-athletes-companies-sponsor-not-olympics

Scassa, T. (2014, January). Ambush marketing legislation to protect Olympic sponsors: A step too far in the name of brand protection? In B. C. Doagoo, M. Goudreau, M. Saginur, \& T. Scassa (Eds.), Intellectual property for the 21st Century (pp. 500-520). Irwin Law: Ottawa, Canada.

Schreiber, C. (2019-20). What is real? Authenticity, transparency, and trust in the digital age of fashion: II. Case comments: Cullinane v. Uber Technologies, Inc., New York Law School Review, 64, 287- 299.

South African Sports Confederation and Olympic Committee. (2020). Commercial regulations for participants during the Tokyo 2020 Olympic Games. SASCOC. Retrieved from https://www. sascoc.co.za/wp-content/uploads/2020/02/SASCOC-Rule-40.pdf

Shontz, L. (2016, July 27). Olympic rules leave non-sponsors with few words. Runners World. Retrieved from https://www.runnersworld.com/news/a20812737/olympic-rule-leaves-non-sponsors-with-few-words/

Smart \& Biggar. (2018, February 6). Danger in the Korean peninsula: Ambush marketing and the Olympic Games. JDSUPRA. Retrieved from https://www.jdsupra.com/legalnews/danger-in-the-korean-peninsula-ambush-10802/

Snyder, M. F., \& Denisco, E. A. (2018, February 26). The challenge of trying to compete with Team USOC. Imagine That IP Lawe Blog. Retrieved from https://www.vklaw.com/ImagineThatIPLawBlog/the-challenge-of-trying-to-compete-with

Tsvetanova, V. (2020, February 19). How competition law is shaping Olympic sponsorship: Part 1 - the origins and evolution of Rule 40. Retrieved from https://www.lawinsport.com/topics/ item/how-competition-law-is-shaping-olympic-sponsorship-part-1-the-origins-and-evolutionof-rule-40

Ted Stevens Olympic and Amateur Sports Act of 1998. 36 U.S.C. § 220521 et seq. (2016).

United States Olympic \& Paralympic Committee. (2019, October 7). Athlete marketing for the Olympic and Paralympic Games Tokyo 2020 - Rule 40 guidance for the United States (Personal Sponsor Commitment document). (link has been removed until 2021).

White, A. M. (2020, Spring). Stop teaching consideration. Nevada Law Journal, 20, 503-545.

Wuthrich, M. (2016, April). Protecting the Olympic properties. WIPO Magazine. Retrieved from https://www.wipo.int/wipo magazine/en/2016/04/article 0004.html 